\title{
Impact of non-invasive mechanical ventilation (niv) in critical patients with influenza (H1N1) PDM09
}

\author{
C Ferri ${ }^{1 *}$, J Marin-Corral ${ }^{1}$, M Magret ${ }^{1}$, M Bodí ${ }^{1}, 2$, S Trefler ${ }^{1}$, E Díaz ${ }^{3}$, I Martín-Loeches ${ }^{4}$, JC Yébenes ${ }^{5}$, C Cilloniz ${ }^{6}$, \\ J Masclans', F Gordo-Vidal', L Cordero' ${ }^{9}$, A Rodríguez ${ }^{1,2}$
}

From ESICM LIVES 2015

Berlin, Germany. 3-7 October 2015

\section{Introduction}

The use of non-invasive mechanical ventilation (NIV) in patients with influenza A (H1N1)pdm09 admitted to intensive care units (ICU) has been controversial.

\section{Objectives}

Our objective was to assess the incidence of failure in NIV in this group of patients and their impact on ICU mortality rate.

\section{Methods}

Secondary analysis of prospective observational multicentric study in 148 spanish ICUs. Data was obtained of GTEI / SEMICYUC (2009-2014) registry. All patients with Influenza Virus A (H1N1) confirmed with rt-PCR were included. Ventilatory strategy, demographics and hemodynamic data, comorbidities and severity indexes were evaluated and they were correlated with mortality. Chi-square (categorical variables) and " $t$ " test or Mann-Whitney test (continuous variables) analysis were performed. Significant variables in the univariate analysis were included in a multivariate model (conditional logistic regression). A "p" value less than 0.05 was considered significant.

\section{Results}

2.223 patients were included in the analysis with a mortality $21.1 \%(\mathrm{n}=470$ patients). 1726 patients were ventilated (77.6\%), $962(55.7 \%)$ of them were initially intubated, and in $764(44.3 \%)$ NIV was initiated. NIV failed in $464(60.7 \%)$ while 300 patients were responders (39.3\%). Patients who died presented: older age (53.5

${ }^{1}$ Hospital Universitari Joan XXIII de Tarragona, Critical Care Department, Tarragona, Spain

Full list of author information is available at the end of the article
[15.34] vs. $48.5[15.1], \mathrm{p}=0.000)$, predominantly male $(65 \%$ vs. $35 \%, \mathrm{p}=0.000)$, higher APACHEII (21[8] vs.14 [6], $\mathrm{p}=0.000)$ and SOFA (8[3] vs. 5[3], $\mathrm{p}=0.000)$, more shock $(79 \%$ vs. $44 \%, \mathrm{p}<0.000)$, more acute renal failure $(49 \%$ vs. $18 \%, \mathrm{p}=0.000)$, more comorbidities (asthma, heart failure, renal failure and immunosuppression, $\mathrm{p}<0.001)$, more days of mechanical ventilation (12.9[13.4] vs.9.4[13.2], $\mathrm{p}=0.000)$ and longer hospital stay $(23.2[19.3]$ vs. $16.6[15.6] \mathrm{p}=0.000)$. NIV failed group patients, had higher mortality (36\%) than NIV successful group $(4 \%, \mathrm{p}=0.000)$ and initially intubated group $(31 \%, p=0.07)$. Furthermore, the failure of NIV (OR=10.2, 95\%IC 5.28-19.76, $\mathrm{p}=0.000$ ), the APACHEII $(\mathrm{OR}=1,05,95 \% \mathrm{IC} 1.02-1.09, \mathrm{p}=0.004)$, acute renal failure $(\mathrm{OR}=2.48,95 \%$ IC 1.52-4.05, $\mathrm{p}=0.000)$ and immunodeficiency $(\mathrm{OR}=5.66,95 \% \mathrm{IC} 3.02-10.60, \mathrm{p}=0.000)$ were independently variables associated with mortality in the multivariate analysis.

\section{Conclusions}

In our population of patients with influenza A (H1N1) pdm09, the failure of NVI is frequently and is associate independently with the ICU mortality.

\section{Acknowledgment \\ We are thankful to SEMICYUC/GETGAG working group \\ Authors' details \\ 'Hospital Universitari Joan XXIII de Tarragona, Critical Care Department, Tarragona, Spain. ${ }^{2}$ CIBERES (CIBER Enfermedades Respiratorias), Palma de Mallorca, Spain. ${ }^{3}$ Parc Taulí Hospital, Critical Care Department, Sabadell, Spain. ${ }^{4}$ Multidisciplinary Intensive Care Research Organization (MICRO). St. James university Hospital. Trinity Centre For Health Sciencies, Department of Anaesthesia and Critical Care, Dublin, Ireland. ${ }^{5}$ Hospital de Mataró, Critical Care Department, Mataró, Spain. ${ }^{6}$ Hospital Clinic de Barcelona, Critical Care Department, Barcelona, Spain. ${ }^{7}$ Hospital del Mar, Critical Care Department,}

(c) 2015 Ferri et al.; This is an Open Access article distributed under the terms of the Creative Commons Attribution License (http:// creativecommons.org/licenses/by/4.0), which permits unrestricted use, distribution, and reproduction in any medium, provided the original work is properly cited. 
Barcelona, Spain. ${ }^{8}$ Hospital de Henares, Critical Care Department, Madrid, Spain. ${ }^{9} \mathrm{CH} \cup A C$, Critical Care Department, A Coruña, Spain.

Published: 1 October 2015

\section{Reference}

1. Recommendations of the Infectious Diseases Work Group (GTEI) of the Spanish Society of Intensive and Critical Care Medicine and Coronary Units (SEMICYUC) and the Infections in Critically III Patients Study Group (GEIPC) of the Spanish Society of Infectious Diseases and Clinical Microbiology (SEIMC) for the diagnosis and treatment of influenza A/H1N1 in seriously ill adults admitted to the Intensive Care Unit Med Intensiva 2012, 36(2):103-37, Mar.

doi:10.1186/2197-425X-3-S1-A702

Cite this article as: Ferri et al:: Impact of non-invasive mechanical ventilation (niv) in critical patients with influenza (H1N1) PDM09. Intensive Care Medicine Experimental 2015 3(Suppl 1):A702.

\section{Submit your manuscript to a SpringerOpen ${ }^{\circ}$ journal and benefit from:}

- Convenient online submission

- Rigorous peer review

- Immediate publication on acceptance

- Open access: articles freely available online

- High visibility within the field

- Retaining the copyright to your article

Submit your next manuscript at $\gg$ springeropen.com 